\title{
All-cause and cause-specific mortality in rheumatoid arthritis are not greater than expected when treated with tumour necrosis factor antagonists
}

\author{
Loreto Carmona, Miguel Ángel Descalzo, Eva Perez-Pampin, \\ Dolores Ruiz-Montesinos, Alba Erra, Tatiana Cobo, \\ Juan J Gómez-Reino, on behalf of the BIOBADASER and \\ EMECAR Groups*
}

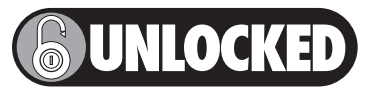

This paper is freely available online under the BMJ Journals unlocked scheme, see http://ard.bmj.com/info/unlocked.dtl
See end of article for authors' affiliations

Correspondence to: Dr J J Gómez-Reino, Rheumatology Service, Department of Medicine, Hospital Clínico

Universitário, A Choupana $\mathrm{s} / \mathrm{n}, 15706$ Santiago, Spain; juan.gomez-reino. carnota@sergas.es

Accepted 19 February 2007 Published Online First 23 February 2007
Background: Mortality is increased in rheumatoid arthritis (RA), mainly because of cardiovascular (CV) events, cancer and infections. Recent data suggest that treatment with tumour necrosis factor (TNF) antagonists may affect this trend.

Objective: To assess whether treatment with TNF antagonists is associated with reduction in CV events, cancer and infection rates, and in mortality in patients with RA treated and not treated with TNF antagonists.

Methods: BIOBADASER is a registry for active long-term follow-up of safety of biological treatments in patients with RA. It includes 4459 patients with RA treated with TNF antagonists. EMECAR is an external RA cohort $(n=789)$ established to define the characteristics of the disease in Spain and to assess comorbidity. The incidence density (ischaemic heart disease) of CV events, cancer and infections was estimated and compared. The standardised mortality ratio was compared with the rate in the general population. A propensity score was used to match cohorts by the probability of being treated.

Results: Rates of CV and cancer events are significantly higher in EMECAR than in BIOBADASER (RR 5-7 for different CV events, and RR 2.9 for cancer), whereas the rate of serious infections is significantly higher in BIOBADASER (RR 1.6). Mortality ratio of BIOBADASER by EMECAR is $0.32(0.20-0.53)$ for all causes of death, $0.58(0.24-1.41)$ for $C V$ events, $0.52(0.21-1.29)$ for infection and $0.36(0.10-1.30)$ for cancerrelated deaths.

Conclusion: Morbidity, other than infection, and mortality are not higher than expected in patients with RA treated with TNF antagonists.

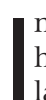
most studies, mortality in rheumatoid arthritis (RA) is higher than expected. ${ }^{1-3}$ This excess of mortality pertains largely to cardiovascular (CV) diseases as in the general population, yet in $\mathrm{RA}^{4-7}$ traditional $\mathrm{CV}$ risk factors do not satisfactorily account for the surplus of deaths. ${ }^{8}$ In fact, high levels of inflammation reflected by activity scores or extraarticular disease are more robust predictors of premature CV mortality than high cholesterol level or high blood pressure. ${ }^{10}{ }^{11}$ In $\mathrm{RA}^{12-14}$ and in artheriosclerosis, ${ }^{15}$ chronic inflammation plays a role as an atherogenic factor. ${ }^{16}$ Early and aggressive control of the inflammation results in improved survival. ${ }^{47-20}$ Additional conditions contributing to the excess of mortality in RA are infections and cancer. Both infections and cancer are related to the extent and severity of arthritis. ${ }^{2112122}$ Interestingly, patients with RA with more severe disease are currently treated with TNF antagonists, which are associated with serious infections and with malignancies, ${ }^{23}$ and deterioration of heart function and heart failure. ${ }^{24}$ Taking all this information together, our objective in the present work was to analyse the net effect of TNF antagonists on all-cause mortality in RA, and particularly on death from CV disease, malignancies and infectious causes. ${ }^{16-20} 25-27$

\section{PATIENTS AND METHODS}

The present study is based on the comparison of two nationwide cohorts, one available from a drug registry, BIOBADASER (2001-6), and the other, EMECAR (1999-2005), from a cohort of patients with RA. Both BIOBADASER and EMECAR cohort studies were approved by their corresponding ethical committees.

The BIOBADASER cohort

A description of BIOBADASER has been published elsewhere. ${ }^{28-30}$ BIOBADASER is a drug safety registry launched in February 2000 for active long-term follow-up of patients with RA treated with biological response modifiers. The registry has generated an open cohort of patients in 100 participating centres of patients starting treatment for the first time with a TNF antagonist and followed thereafter. The registry protocol and materials were approved by the Spanish Medicines Agency, and data regarding patients were gathered according to the present official regulations on data protection. Any change in the treatment as well as relevant adverse events (AEs) occurring during follow-up are registered.

Data collected systematically include gender, date of birth, diagnosis and date of diagnosis of the patients, treatment type and dates of initiation and of discontinuation of the treatment. When a patient has a relevant $\mathrm{AE}$, additional data are registered, including the date of occurrence, type and classification of $\mathrm{AE}$ according to the World Health Organization Dictionary of adverse drug reactions, outcome of $\mathrm{AE}$, concomitant treatment and comorbidity. AEs are reported as they occur. Once a year, all participants are requested to update the

Abbreviations: $A E$, adverse event; $C V$, cardiovascular; $D A S$, disease activity score; RA, rheumatoid arthritis; SMR, standardised mortality ratio; TNF, tumour necrosis factor 


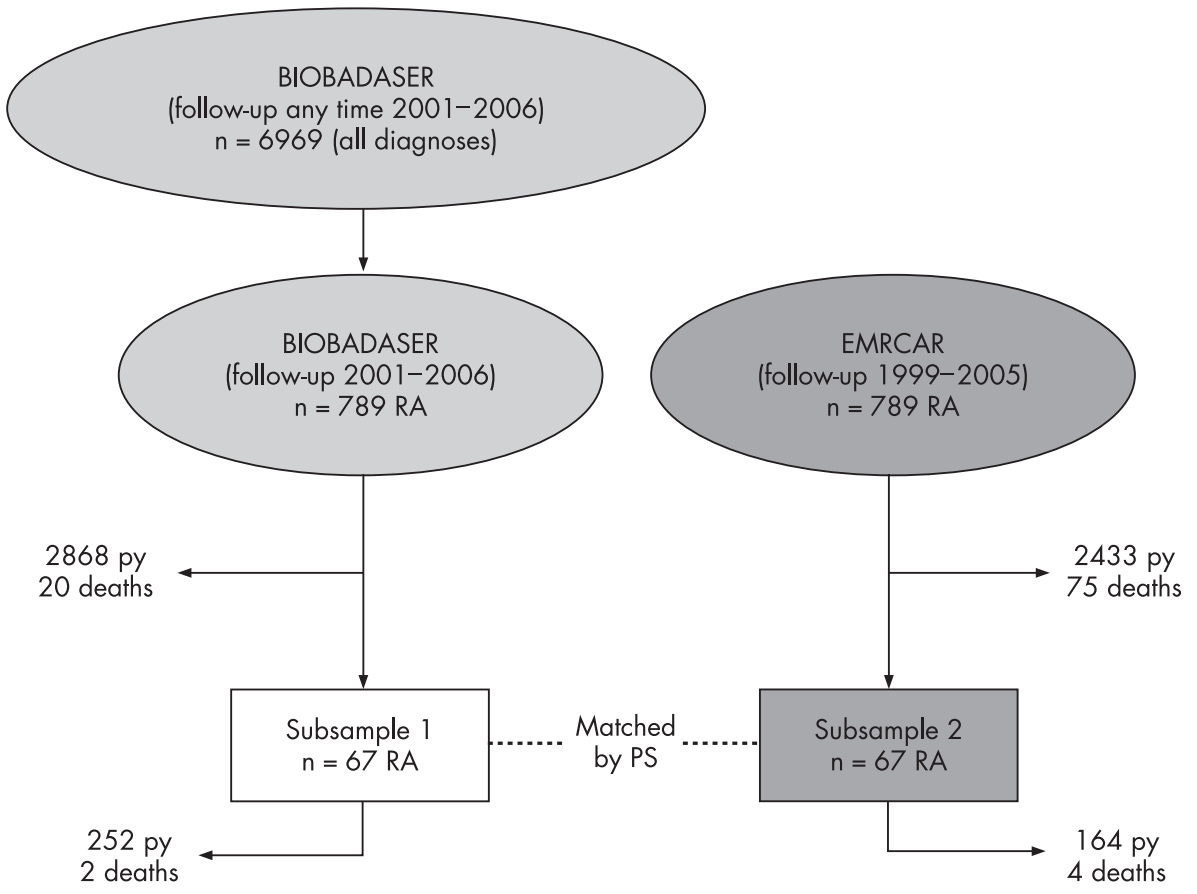

Figure 1 Flow chart of the selection of patients to make patients in both cohorts comparable. In BIOBADASER, only patients with rheumatoid arthritis starting treatment with a tumour necrosis factor antagonist before 2002 were included, thus assuring an equal length of follow-up of 5 years. A sample of patients with known baseline Disease Activity Score using 28 joint counts (DAS 28 was obtained from four participating centres (subsample 1) and used to match by propensity score (PS) with patients from EMECAR (subsample 2).

patients registered in their centre, prior to downloading the database for analysis. Furthermore, completeness and agreement of data with patients' charts are assessed in situ by yearly audits of $10 \%$ of the patients registered in BIOBADASER, chosen randomly. A total of 665 clinical records from 82 centres were reviewed in the audit before the present analysis; $14 \%$ of entries had errors in notifications. All inaccuracies were corrected accordingly, yielding an expected error of $11 \%$. Patients coming from centres where the audits revealed incompleteness of the data $(n=12)$ were censored at the time of the last reliable information. To improve comparability with the EMECAR cohort, only data from patients with RA who had been in the registry before January 2002 were analysed $(\mathrm{n}=789)$, thus ensuring a similar observation time of 5 years with EMECAR.

\section{The EMECAR cohort}

The EMECAR cohort has also been described previously. ${ }^{31-33}$ It comprises 789 patients in whom clinical expression, disease activity and progression of the disease, and comorbidity have been prospectively collected in yearly visits for 5 years according to a structured protocol. EMECAR strengths are that (1) it represents the Spanish population with RA, as it was assembled by random sampling from clinical databases of 34 rheumatology units; (2) it was started in 1999, before any biological treatment was available in Spain; and (3) it was assembled specifically to assess comorbidity and mortality in RA. For the present study, all data on patients in EMECAR who were treated during the observational period with TNF antagonists were censored at the time of the first dose. The numbers of patients starting treatment with TNF antagonists in EMECAR at 1,3 and 5 years of follow-up were 11 (1.4\%), 63 (10.5\%) and $78(16.8 \%)$, respectively.

\section{The BIOBADASER subsample}

As neither comorbidity nor clinical data were collected at baseline in BIOBADASER, four participating centres were asked to report these specific data. The centres were selected on the following bases: (a) being from four different regions (north, south, east and central Spain); (b) having contributed information on at least 100 patients in the registry; and (c) having their patients in prospective clinical cohorts, thus ensuring good-quality data. In total, these four centres contributed information on 437 patients with RA (67 in the registry before January 2002). Figure I shows the flow of selection of patients to make both cohorts comparable.

\section{Definitions of risk factors and cause of death}

The working definitions of $\mathrm{CV}$ risk factors in the four BIOBADASER centres and EMECAR were similar: (1) Hypercholesterolaemia was defined as a cholesterol level $>240 \mathrm{mg} / \mathrm{dl}(6.5 \mathrm{mmol} / \mathrm{l})$ in two separated occasions, or need for cholesterol-lowering medication; (2) Hypertension was defined as a systolic blood pressure $\geqslant 140 \mathrm{~mm} \mathrm{Hg}$, or as a diastolic blood pressure $\geqslant 90 \mathrm{~mm} \mathrm{Hg}$, or the need for antihypertensive treatment; (3) Diabetes was defined by the National Institute of Health National Diabetes Data Group criteria of 1979 as fast glucose level $\geqslant 7.8 \mathrm{mmol} / \mathrm{l}$ ( $140 \mathrm{mg} / \mathrm{dl}$ ) in two separate occasions, or a glucose level $\geqslant 11.1 \mathrm{mmol} / \mathrm{l}$ $(200 \mathrm{mg} / \mathrm{dl}) 2 \mathrm{~h}$ after taking $75 \mathrm{~g}$ of oral glucose in two separate occasions; (4) Obesity was defined as a body mass index $\geqslant 30 \mathrm{~kg} / \mathrm{cm}^{2}$. "Smoking habit" had a broader definition in EMECAR as "ever smoking", whereas in the four BIOBADASER centres a smoking habit was defined as smoking any amount of cigarettes per day at the time of the interview. Date of death and cause of death were obtained from charts, patients' families and regional death registries.

\section{Statistical methods}

Student's $t$ and $\chi^{2}$ tests were used to compare differences in baseline variables in BIOBADASER and EMECAR cohorts. Incidence rates per 100000 patient-years of CV events, infections and cancer, with 95\% CIs, were estimated in the two cohorts. Time of observation for the patients comprised the period from the baseline date until occurrence of any of the following: death from any cause, last reliable audit of a centre (only in BIOBADASER) loss of follow-up, beginning of any biological treatment (only in EMECAR), or end of follow-up. 
Table 1 Baseline characteristics of the patients included in the two cohorts as well as in the two subsamples: subsample 1 includes patients from four BIOBADASER centres, subsample 2 was drawn randomly from EMECAR to match with the BIOBADASER subsample (see Methods: propensity score)

\begin{tabular}{|c|c|c|c|c|}
\hline Descriptor & $\begin{array}{l}\text { BIOBADASER } \\
(\mathrm{n}=789)\end{array}$ & $\begin{array}{l}\text { Subsample } 1 \\
(n=67)\end{array}$ & $\begin{array}{l}\text { EMECAR } \\
(n=789)\end{array}$ & $\begin{array}{l}\text { Subsample } 2 \\
(n=67)\end{array}$ \\
\hline Age (years), mean (SD) & $59(13)$ & $53(13)$ & $61(13)^{*} \dagger$ & $52(11)$ \\
\hline Women, n (\%) & 621 (79) & $54(81)$ & $568(72)^{*}$ & $56(84)$ \\
\hline \multicolumn{2}{|c|}{$\begin{array}{l}\text { Disease Activity Score, mean } \\
\text { (SD) }\end{array}$} & $6.1(1.2)$ & $4.2(1.4) \dagger$ & $5.9(1.1)$ \\
\hline \multicolumn{2}{|c|}{$\begin{array}{l}\text { Treated with methotrexate, } \mathrm{n} \\
(\%)\end{array}$} & $20(71)$ & $546(70)$ & $62(93)$ \\
\hline \multicolumn{2}{|c|}{$\begin{array}{l}\text { Hypercholesterolaemia, } \mathrm{n} \\
(\%)\end{array}$} & $14(30)$ & $241(31)$ & $15(22)$ \\
\hline \multicolumn{2}{|l|}{ Diabetes, n (\%) } & $3(7)$ & $70(9)$ & $6(9)$ \\
\hline \multicolumn{2}{|l|}{ Hypertension, $n(\%)$} & $12(26)$ & $286(37)$ & $19(28)$ \\
\hline \multicolumn{2}{|l|}{ Smoking habit, n (\%) } & $4(9)$ & $239(30) \dagger$ & $21(31) \ddagger$ \\
\hline \multicolumn{2}{|l|}{ Obesity, n (\%) } & $10(24)$ & $160(21)$ & $13(19)$ \\
\hline
\end{tabular}

${ }^{*} \mathrm{p}<0.01$ between EMECAR and BIOBADASER.

$t p<0.01$ between EMECAR and BIOBADASER subsamples.

$\neq \mathrm{p}<0.01$ between EMECAR and BIOBADASER subsamples.

Standardised mortality ratios (SMRs) with 95\% CIs were calculated as the ratio of observed by expected deaths by the indirect method, using the 2002 population mortality data of all-cause and cause-specific deaths. Data on Spanish mortality stratified by age and gender were obtained from the National Institute of Statistics (Instituto Nacional de Estadística). Mortality ratios and $95 \%$ CIs between both cohorts were also calculated, as an effect measure.

Because of a small but statistically significant difference in baseline disease severity between BIOBADASER and EMECAR cohorts, the probability of being treated with biologicals (propensity score) was used to match cases from the BIOBADASER subsample with controls from the single nearest-neighbour in EMECAR. The propensity score included baseline age, DAS28, disease duration and gender, and it was calculated with STATA-specific commands. ${ }^{34}$ The resulting data file of cases and controls was used to compare the effect of exposure to TNF antagonists on mortality, by means of the rate ratio. All analyses were performed by using the statistical program STATA V.9.2.

\section{RESULTS}

The selected cohorts with RA provided information on 2868 patient-years treated with TNF antagonists (BIOBADASER) and 2433 patient-years (EMECAR) not treated with TNF antagonists. Table 1 shows baseline characteristics of the patients in the two cohorts as well as in the two subsamples; one from the four BIOBADASER centres with prospective cohorts and the other from the controls in the EMECAR cohort matched by the propensity score.

Patients in the EMECAR cohort showed a CV profile similar to the patients in BIOBADASER, except for EMECAR patients being 2 years older and having a higher prevalence of smoking, perhaps because of a broader definition of smoking.

\section{Incidence of CV events, infections and cancer}

Table 2 shows the incidence of CV events, infections and cancer in the cohorts, with 95\% CIs, in BIOBADASER and in EMECAR. Rates of all CV events and of cancer are significantly higher in EMECAR than in BIOBADASER, whereas the rate of serious infections is higher in BIOBADASER. Given the difference in age

Table 2 Incidence of cardiovascular events, infections and cancer per 100000 patients-years, with $95 \% \mathrm{Cls}$, in the two cohorts

\begin{tabular}{|c|c|c|c|c|c|c|}
\hline & \multicolumn{3}{|c|}{ BIOBADASER } & \multicolumn{3}{|c|}{ EMECAR } \\
\hline & Cases & Patient-years & Incidence rate & Cases & Patient-years & Incidence rate \\
\hline Ischaemic heart disease & 4 & 2855 & 140 (53 to 373$)$ & 20 & 2269 & 881 (569 to 1366 ) \\
\hline Younger than 60 & 1 & 1548 & $65(9$ to 459$)$ & 1 & 760 & 132 (19 to 934) \\
\hline 60 or older & 3 & 1307 & 229 (74 to 712$)$ & 19 & 1509 & 1259 (803 to 1974) \\
\hline Cardiac failure & 5 & 2860 & 175 (73 to 420$)$ & 28 & 2269 & 1234 (852 to 1787 ) \\
\hline$<60$ years & 0 & 1552 & 0 & 0 & 760 & 0 \\
\hline 60 or older & 5 & 1308 & 382 (159 to 918$)$ & 28 & 1509 & 1855 (1281 to 2687$)$ \\
\hline Stroke & 3 & 2858 & 105 (34 to 326$)$ & 14 & 2269 & 617 (365 to 1042) \\
\hline$<60$ years & 1 & 1552 & 64 (9 to 457$)$ & 2 & 760 & 263 (66 to 1052 ) \\
\hline$\geqslant 60$ years & 2 & 1306 & 153 (38 to 612) & 12 & 1509 & 795 (452 to 1400 ) \\
\hline Infections & 114 & 2644 & 4312 (3589 to 5181$)$ & 63 & 2269 & 2776 (2169 to 3554 ) \\
\hline$<60$ years & 41 & 1452 & 2823 (2079 to 3834 ) & 12 & 760 & 1579 (897 to 2780 ) \\
\hline$<60$ years & 73 & 1192 & $6126(4870$ to 7706$)$ & 51 & 1509 & 3379 (2568 to 4446 ) \\
\hline Cancer & 11 & 2879 & 382 (212 to 690$)$ & 23 & 2265 & 1103 (746 to 1633 ) \\
\hline$<60$ years & 7 & 1318 & 256 (96 to 683 ) & 3 & 760 & 526 (198 to 1402) \\
\hline$\geqslant 60$ years & 4 & 1561 & 531 (253 to 1115 ) & 20 & 1505 & 1395 (910 to 2140$)$ \\
\hline
\end{tabular}


Table 3 Standardised mortality ratios and $95 \% \mathrm{Cls}$ of patients with rheumatoid arthritis treated or not with tumour necrosis factor antagonists with respect to the expected rate in the general population of Spain

\begin{tabular}{|c|c|c|c|}
\hline & BIOBADASER & EMECAR & Mortality rate ratios* \\
\hline All causes & $0.516(0.315$ to 0.797$)$ & 1.493 (1.174 to 1.872$)$ & \multirow[t]{3}{*}{$0.32(0.20$ to 0.53$) \dagger$} \\
\hline Men & $0.469(0.152$ to 1.095$)$ & 1.548 (1.059 to 2.185$)$ & \\
\hline Women & $0.534(0.299$ to 0.881$)$ & $1.455(1.053$ to 1.960$)$ & \\
\hline Cardiovascular & $0.510(0.205$ to 1.050$)$ & $0.937(0.546$ to 1.450$)$ & \multirow[t]{3}{*}{$0.58(0.24$ to 1.41$)$} \\
\hline Men & $1.281(0.349$ to 3.281$)$ & $1.227(0.530$ to 2.417$)$ & \\
\hline Women & $0.283(0.058$ to 0.826$)$ & $0.774(0.354$ to 1.470$)$ & \\
\hline Infectious & $11.294(4.541$ to 23.270$)$ & $18.676(10.210$ to 31.335$)$ & \multirow[t]{3}{*}{$0.52(0.21$ to 1.29$)$} \\
\hline Men & $5.589(0.142$ to 31.141$)$ & 10.069 (2.077 to 29.427$)$ & \\
\hline Women & 13.609 (4.994 to 29.622$)$ & 24.352 (12.156 to 43.572$)$ & \\
\hline Cancer & $0.284(0.059$ to 0.831$)$ & $0.988(0.526$ to 1.689$)$ & \multirow[t]{3}{*}{$0.36(0.10$ to 1.30$)$} \\
\hline Men & 0.000 (0.000 to 0.952$)$ & $1.660(0.829$ to 2.970$)$ & \\
\hline Women & $0.450(0.093$ to 1.314$)$ & $0.306(0.037$ to 1.106$)$ & \\
\hline $\begin{array}{l}\text { Mortality ratios } \\
{ }^{*} \text { Adjusted by age } \\
t p<0.001 .\end{array}$ & Is (BIOBADASER/EMECAR). & & \\
\hline
\end{tabular}

in the comparison cohort, incidence rates were stratified by age, 60 years being the stratifying level. Despite the small size of the strata, patients aged $>60$ years showed a significant difference rate of ischaemic heart disease and cardiac failure in both cohorts.

\section{Mortality}

A total of 75 patients in the EMECAR cohort died ( 32 men and 43 women), but only 50 were expected to die. The main causes of death were CV disease $(n=17 ; 23 \%)$, infection $(n=14 ; 19 \%)$ and cancer $(\mathrm{n}=13 ; 17 \%)$. The cause of death was unknown in 14 (19\%) patients. In the BIOBADASER cohort, 20 patients died in the same period ( 5 men and 15 women), but 38 were expected to die. The main causes of death, known in all cases, were infections $(\mathrm{n}=7 ; 35 \%), \mathrm{CV}$ disease $(\mathrm{n}=7 ; 35 \%)$ and cancer $(\mathrm{n}=3 ; 15 \%)$. Table 3 shows SMRs in BIOBADASER and EMECAR, by cause of death and sex, and mortality ratios, adjusted by age and sex, between both cohorts (BIOBADASER/EMECAR).

When subsamples matched by the propensity score were analysed, SMR for all causes changed in BIOBADASER from a $50 \%$ to a $40 \%$ reduction and SMR 0.648 (0.079 to 2.342$)$; SMR of men 0 (0 to 6.743), SMR of women 0.788 (0.096 to 2.847). In EMECAR, the change was even more noticeable, with SMR 3.052 (0.832 to 7.814); SMR of men 1.633 (0.041 to 9.100), SMR of women 4.296 (0.886 to 12.554). Given the small sample size, only death from all causes was analysed. The MRR of the BIOBADASER subsample by the EMECAR subsample was 0.324 (0.06 to 1.77), 0.224 (0.04 to 1.31) adjusted by age, and 0.191 (0.03 to 1.30 ) adjusted by age and gender, reaching significance $(\mathrm{p}=0.10)$.

\section{DISCUSSION}

In the present study, we have investigated the impact of TNF antagonists on the survival of patients with RA. Our study shows that mortality from non-infectious causes is decreased in this selected population as compared with patients with RA not exposed to TNF antagonists. Furthermore, reduction in mortality from cardiac causes seems to be the major reason for this decline. However, a significant increase in the rate of relevant infections in patients treated with TNF antagonists occurs.

There are some limitations to our study. The control cohort was not a true internal cohort. However, the EMECAR cohort was assembled from $90 \%$ of hospitals actively including patients in the BIOBADASER registry, and therefore patients in both BIOBADASER and EMECAR cohorts should have received similar care. Patients in EMECAR have milder activity (baseline DAS) and this may be the reason why only few patients received TNF antagonists when available. Nevertheless, EMECAR may replicate the improvement in survival associated with the recent awareness that a more aggressive and early control of disease activity should be the standard of treatment in RA. ${ }^{18}{ }^{35}{ }^{36}$ BIOBADASER patients were on average 2 years younger than EMECAR patients. This may have an impact on CV morbidity and mortality, balanced nonetheless by the larger number of women in EMECAR with a lower mortality. Of note, comorbidities in EMECAR did not diverge substantially from BIOBADASER except for hypertension and smoking habits, both related perhaps to a more active search in EMECAR (designed specifically to study comorbidity in RA) than to a true high prevalence. Activity, and not other factors, was the major drive for the use of TNF antagonists in BIOBADASER. Thus, a bias to the use of TNF antagonists in patients with fewer comorbidities or absence of comorbidities associated with higher mortality does not seem to be the explanation for the differences in mortality in our study. Nevertheless, observational studies of exposed and unexposed patients may differ systematically with regard to variables related to exposure or outcome. However, adjustment by matching exposed and unexposed patients with regard to known conditional exposure prognostic variables (propensity score) as in our work leads to unbiased estimates and tests of exposure effect. ${ }^{37}{ }^{38}$ Another potential bias is the incompleteness of the data in BIOBADASER. If we assume $11 \%$ error, as revealed by repeated audits, the mortality would still be lower than expected. In the worst scenario, the number of deaths would be 22 instead of 20, the number of patient-years of follow-up 2868 I instead of 2550, and the MRR of BIOBADASER by EMECAR 0.280 (0.166 to 0.455$)$.

As the doctors involved in the care of EMECAR patients were largely the same as those treating BIOBADASER patients, the reporting of causes of death should not have differed significantly. This issue may be relevant in the case of deaths from cancer, attributed, on occasions to infection or CV events rather than to the primary condition especially in elderly patients with comorbidities..$^{39}$ Still, the cause of death in EMECAR was unknown in a number of cases. If all these deaths are attributed to a CV cause as is commonly the case, the difference with BIOBADASER would be even larger. On the contrary, attributing the unknown causes of death to infection would probably be more realistic, ${ }^{41}$ and the rate of deaths from infection in EMECAR and BIOBADASER would be similar. 
Basic and clinical studies have demonstrated that CV damage in RA may be, in part, due to a deleterious effect of TNF on the endothelium..$^{42}{ }^{43}$ Present data show that TNF blockade is able to partially normalise endothelial function in patients with RA. ${ }^{44}$ Furthermore, an impact of TNF antagonists on the CVrelated mortality has been suggested by preliminary reports ${ }^{46} 47$ and supported by the finding of a large number of $\mathrm{TNF} \alpha$ producing monocytes in fresh thrombi from patients with myocardial infarction. ${ }^{48}$

It could be proposed that patients treated with TNF antagonists could have undergone closer follow-up and control of comorbidities. This may be one of the reasons why death from cancer, CV disease and infection was lower in BIOBADASER than in EMECAR, despite a higher rate of relevant infections in BIOBADASER. The low rate of death from cancer has been published previously. ${ }^{49}$ By contrast, recent meta-analysis of randomised controlled trials showed a clear increase in the incidence of cancer in clinical trials..$^{50}$ Nevertheless, observational studies have failed to demonstrate such increases in mortality compared with patients with RA not treated with TNF antagonists. This issue needs further investigation.

Finally, comparison of TNF antagonists would have been interesting. Unfortunately, our samples were too small for this purpose. Besides, the observation time for all three biologicals was different as they became available at different times, which may also have an impact on mortality.

In conclusion, mortality in patients with RA who have been treated with TNF antagonists is not different from the general population of similar age and gender. Furthermore, mortality in this cohort of patients is clearly reduced compared with patients with RA not treated with TNF antagonists, owing to the reduction of deaths from non-infectious causes.

\section{ACKNOWLEDGEMENTS}

The BIOBADASER registry is supported by the Spanish Society of Rheumatology and by the Spanish Medicines and Medical Devices Agency. Started in year 2006, BIOBADASER is also supported by grants of similar quantity from Schering-Plough, Wyeth, Abbott Immunology, Roche Farma and Bristol-Myers Squibb, Spain. The EMECAR cohort was supported by the Spanish Society of Rheumatology and by Aventis. We are indebted to Raquel Ruiz for her secretarial work and diligence with all her commitments in the studies.

\section{Authors' affiliations \\ Loreto Carmona, Miguel Ángel Descalzo, Research Unit, Spanish \\ Foundation of Rheumatology, Madrid, Spain \\ Eva Perez-Pampin, Juan J Gómez-Reino, Rheumatology Service, \\ Department of Medicine, Hospital Clinico Universitario, Medical School, \\ Universidad de Santiago de Compostela, Santiago de Compostela, Spain \\ Dolores Ruiz-Montesinos, Rheumatology Service, Hospital Virgen \\ Macarena, Sevilla, Spain \\ Alba Erra, Rheumatology Service, Hospital Vall d'Hebron, Barcelona, \\ Spain \\ Tatiana Cobo, Rheumatology Service, Hospital La Paz, Madrid, Spain}

Competing interests: JJGR is on the Advisory Boards of Wyeth and Schering Plough, and has received lectures fees from Abbott, Wyeth, and Schering Plough.

${ }^{*}$ Author list appears in the appendix.

\section{REFERENCES}

Myllykangas-Luosujarvi RA, Aho K, Isomaki HA. Mortality in rheumatoid arthritis. Semin Arthritis Rheum 1995;25:193-202.

2 Wolfe F, Mitchell DM, Sibley JT, Fries JF, Bloch DA, Williams CA, et al. The mortality of rheumatoid arthritis. Arthritis Rheum 1994;37:481-94.

3 Mikuls TR, Saag KG, Criswell LA, Merlino LA, Kaslow RA, Shelton BJ, et al. Mortality risk associated with rheumatoid arthritis in a prospective cohort of older women: results from the lowa Women's Health Study. Ann Rheum Dis 2002;61:994-9.
4 Goodson N, Marks J, Lunt M, Symmons D. Cardiovascular admissions and mortality in an inception cohort of patients with rheumatoid arthritis with onset in the 1980s and 1990s. Ann Rheum Dis 2005;64:1595-601

5 Maradit-Kremers H, Nicola PJ, Crowson CS, Ballman KV, Gabriel SE. Cardiovascular death in rheumatoid arthritis: a population-based study. Arthritis Rheum 2005;52:722-32.

6 Goodson NJ, Wiles NJ, Lunt M, Barrett EM, Silman AJ, Symmons DP. Mortality in early inflammatory polyarthritis: cardiovascular mortality is increased in seropositive patients. Arthritis Rheum 2002:46:2010-19.

7 Wallberg-Jonsson S, Ohman ML, Dahlqvist SR. Cardiovascular morbidity and mortality in patients with seropositive rheumatoid arthritis in Northern Sweden. $J$ Rheumatol 1997;24:445-51.

8 Goodson NJ, Silman AJ, Pattison DJ, Lunt M, Bunn D, Luben R, et al. Traditional cardiovascular risk factors measured prior to the onset of inflammatory polyarthritis. Rheumatology (Oxford), 2004;43:731-6.

9 del Rincon ID, Williams K, Stern MP, Freeman GL, Escalante A. High incidence of cardiovascular events in a rheumatoid arthritis cohort not explained by traditional cardiac risk factors. Arthritis Rheum 2001:44:2737-45.

10 Wallberg-Jonsson S, Johansson H, Ohman ML, Rantapaa-Dahlqvist S. Extent of inflammation predicts cardiovascular disease and overall mortality in seropositive rheumatoid arthritis. A retrospective cohort study from disease onset J Rheumatol 1999;26:2562-71.

11 Chehata JC, Hassell AB, Clarke SA, Mattey DL, Jones MA, Jones PW, et al. Mortality in rheumatoid arthritis: relationship to single and composite measures of disease activity. Rheumatology (Oxford), 2001;40:447-52.

12 Gonzalez-Juanatey C, Gonzalez-Gay MA. Rheumatoid arthritis and accelerated atherogenesis. Circulation 2004;109:e328.

13 Del Rincon I, Williams K, Stern MP, Freeman GL, O'Leary DH, Escalante A. Association between carotid atherosclerosis and markers of inflammation in rheumatoid arthritis patients and healthy subjects. Arthritis Rheum 2003:48: 1833-40.

14 Ross R. Atherosclerosis - an inflammatory disease. N Engl J Med 1999:340:115-26.

15 Khera A, de Lemos JA, Peshock RM, Lo HS, Stanek HG, Murphy SA, et al Relationship between C-reactive protein and subclinical atherosclerosis: the Dallas Heart Study. Circulation 2006;1 13:38-43.

16 Gonzalez-Juanatey C, Llorca J, Testa A, Revuelta J, Garcia-Porrua C, GonzalezGay MA. Increased prevalence of severe subclinical atherosclerotic findings in long-term treated rheumatoid arthritis patients without clinically evident atherosclerotic disease. Medicine (Baltimore), 2003;82:407-13.

17 Goodson N. Coronary artery disease and rheumatoid arthritis. Curr Opin Rheumatol 2002;14:115-20.

18 Krishnan E, Lingala VB, Singh G. Declines in mortality from acute myocardial infarction in successive incidence and birth cohorts of patients with rheumatoid arthritis. Circulation 2004;110:1774-9.

19 Krause D, Schleusser B, Herborn G, Rau R. Response to methotrexate treatment is associated with reduced mortality in patients with severe rheumatoid arthritis. Arthritis Rheum 2000;43:14-21.

20 Choi HK, Hernan MA, Seeger JD, Robins JM, Wolfe F. Methotrexate and mortality in patients with rheumatoid arthritis: a prospective study. Lancet 2002;359:1173-7.

21 Symmons DP, Jones MA, Scott DL, Prior P. Longterm mortality outcome in patients with rheumatoid arthritis: early presenters continue to do well. $J$ Rheumatol 1998;25:1072-7

22 Reilly PA, Cosh JA, Maddison PJ, Rasker JJ, Silman AJ. Mortality and survival in rheumatoid arthritis: a 25 year prospective study of 100 patients. Ann Rheum Dis 1990;49:363-9.

23 van Vollenhoven RF, Askling J. Rheumatoid arthritis registries in Sweden. Clin Exp Rheumatol 2005;23:S195-200.

24 Daniel CL, Moreland LW. Infliximab: additional safety data from an open labe study. J Rheumatol 2002;29:647-9.

25 Antoni C, Braun J. Side effects of anti-TNF therapy: current knowledge. Clin Exp Rheumatol 2002;20:S152-7

26 Cunnane G, Doran M, Bresnihan B. Infections and biological therapy in rheumatoid arthritis. Best Pract Res Clin Rheumatol 2003;17:345-63.

27 Ellerin T, Rubin R, Weinblatt M. Infections and anti-tumor necrosis factor therapy. Arthritis Rheum 2003;48:3013-22.

28 Carmona L, Gomez-Reino JJ, Rodriguez-Valverde V, Montero D, PascualGomez E, Mola EM, et al. Effectiveness of recommendations to prevent reactivation of latent tuberculosis infection in patients treated with tumor necrosis factor antagonists. Arthritis Rheum 2005;52:1766-72.

29 Gomez-Reino JJ, Carmona L, Valverde VR, Mola EM, Montero MD, BIOBADASER Group. Treatment of rheumatoid arthritis with tumor necrosis factor inhibitors may predispose to significant increase in tuberculosis risk: a multicenter active-surveillance report. Arthritis Rheum 2003:48:2122-7.

30 Spanish Society of Rheumatology. BIOBADASER: Spanish Registry for Adverse Events of Biological Therapies in Rheumatic Diseases. Spanish Society of Rheumatology, 2005.

31 Carmona L, Gonzalez-Alvaro I, BalsaA, Belmonte MA, Tena X, Sanmarti R. Rheumatoid arthritis in Spain: occurrence of extra-articular manifestations and estimates of disease severity. Ann Rheum Dis 2003;62:897-900.

32 Carmona L, Hernandez-Garcia C, Vadillo C, Pato E, Balsa A, Gonzalez-Alvaro I, et al. Increased risk of tuberculosis in patients with rheumatoid arthritis. J Rheumatol 2003:30:1436-9.

33 Gonzalez-Alvaro I, Carmona L, Balsa A, Sanmarti R, Belmonte MA, Tena X, et al. Patterns of disease modifying antirheumatic drug use in a Spanish cohort of patients with rheumatoid arthritis. J Rheumatol 2003;30:697-704.

34 Leuven E, Sianesi B, eds. PSMATCH2: Stata module to perform full Mahalanobis and propensity score matching, common support graphing, and covariate imbalance testing, 2003. 
35 Kroot EJ, van Leeuwen MA, van Rijswijk MH, Prevoo ML, Van't Hof MA, van De Putte $L B$, et al. No increased mortality in patients with rheumatoid arthritis: up to 10 years of follow up from disease onset. Ann Rheum Dis 2000;59:954-8.

36 Lindqvist E, Eberhardt K. Mortality in rheumatoid arthritis patients with disease onset in the 1980s. Ann Rheum Dis 1999:58:11-14.

37 D'Agostino RB Jr. Propensity score methods for bias reduction in the comparison of a treatment to a non-randomized control group. Stat Med 1998;17:2265-81.

38 Joffe MM, Rosenbaum PR. Invited commentary: propensity scores. Am J Epidemiol 1999:150:327-33.

39 Grulich AE, Swerdlow AJ, dos Santos Silva I, Beral V. Is the apparent rise in cancer mortality in the elderly real? Analysis of changes in certification and coding of cause of death in England and Wales, 1970-1990. Int J Cancer 1995;63:164-8.

40 Lloyd-Jones DM, Martin DO, Larson MG, Levy D. Accuracy of death certificates for coding coronary heart disease as the cause of death. Ann Intern Med 1998;129:1020-6.

41 Koivuniemi R, Leirisalo-Repo M, Suomalainen R, Piirainen H, Paimela L. Infectious causes of death in patients with rheumatoid arthritis: an autopsy study. Scand J Rheumatol 2006;35:273-6.

42 McLaughlin F, Hayes BP, Horgan CM, Beesley JE, Campbell CJ, Randi AM Tumor necrosis factor (TNF)-alpha and interleukin (IL)-1 beta down-regulate intercellular adhesion molecule (ICAM)-2 expression on the endothelium. Cell Adhes Commun 1998:6:381-400.

43 Mitaka C, Hirata Y, Ichikawa K, Yokoyama K, Emori T, Kanno K, et al. Effects of TNF-alpha on hemodynamic changes and circulating endothelium-derived vasoactive factors in dogs. Am J Physiol 1994;267:H1530-6.

44 Gonzalez-Juanatey C, Testa A, Garcia-Castelo A, Garcia-Porrua C, Llorca J, Gonzalez-Gay MA. Active but transient improvement of endothelial function in rheumatoid arthritis patients undergoing long-term treatment with anti-tumor necrosis factor alpha antibody. Arthritis Rheum 2004;51:447-50.

45 Hurlimann D, Forster A, Noll G, Enseleit F, Chenevard R, Distler O, et al. Antitumor necrosis factor-alpha treatment improves endothelial function in patients with rheumatoid arthritis. Circulation 2002;106:2184-7.

46 Michaud K, Wolfe F. Reduced mortality among RA patients treated with anti-TNF therapy and methotrexate [Abstract]. Arthritis Rheum 2005;52(Suppl):S145.

47 Jude B, Agraou B, McFadden EP, Susen S, Bauters C, Lepelley P, et al. Evidence for time-dependent activation of monocytes in the systemic circulation in unstable angina but not in acute myocardial infarction or in stable angina. Circulation 1994;90:1662-8.

48 Flendrie M, Creemers MC, Welsing PM, den Broeder AA, van Riel PL. Survival during treatment with tumour necrosis factor blocking agents in rheumatoid arthritis. Ann Rheum Dis 2003:62(Suppl 2):ii30-3.

49 Askling J, Fored CM, Baecklund E, Brandt L, Backlin C, Ekbom A, et al. Risks of solid cancers in patients with rheumatoid arthritis and after treatment with tumour necrosis factor antagonists. Ann Rheum Dis 2005;64:1421-6.

50 Bongartz T, Sutton AJ, Sweeting MJ, Buchan I, Matteson EL, Montori V, et al. Anti-TNF antibody therapy in rheumatoid arthritis and the risk of serious infections and malignancies: systematic review and meta-analysis of rare harmful effects in randomized controlled trials. JAMA 2006;295:2275-85.

\section{APPENDIX: BIOBADASER AND EMECAR STUDY GROUPS (IN ALPHABETICAL ORDER)}

Abad MA, Abasolo L, Alegre J, Alegre de Miguel C, Alonso JL, Alonso A, Álvarez A, Álvarez B, Álvaro-Gracia JM, Amengual O,
Andreu JL, Aragón A, Arasa X, Arnal C, Aznar E, Balsa A, Bañegil I, Barastay E, Batlle E, Belmonte MA, Beltrán J, Benito S, Bonilla G, Boquet D, Bosque MT, Buisan A, Cabezas JA, Cáliz R, Calvo J, Calvo I, Campos C, Cantalejo M, Cañete JD, Carbonell J, Carmona L, Carreira P, Carreño L, Casado E, Castro MC, Cebrián L, Centellas M, Chalmeta I, Chamizo E, Ciruelo E, Cobeta JC, Cobo T, Codina O, Collantes E, Coret V, Corrales A, Corteguera M, Crespo M, Cruz A, Cuadra JL, Cuende E, Cuesta E, del Blanco J, Espadaler L, Fernández Campillo J, Fernández Castro M, Fernández Melón J, Fernández Prada M, Ferraz I, Figueroa M, Fiter J, Galindo M, Gallegos A, Gálvez J, García Aparicio A, García Arroba J, García Bernal I, García Borrás JJ, García Consuegra J, García de la Peña P, García de Vicuña R, García Gómez C, García Meijide JA, Gelmán SM, Giménez Úbeda E, Gómez Centeno A, Gómez Vaquero C, Gómez-Reino JJ, González Álvaro I, González Crespo R, González Fernández MJ, González García T, González Gómez ML, González Hernández T, González Molina R, Granados J, Grandal Y, Graña J, Gratacos J, Gutiérrez R, Hernández B, Hernández FF, Hernández del Rio A, Hidalgo C, Ibáñez J, Ibero I, Idalgo C, Iglesias $\mathrm{G}$, Illera $\mathrm{O}$, Instxaurbe $\mathrm{AR}$, Irigoyen $\mathrm{MV}$, Isasi $\mathrm{C}$, Ivorra J, Jiménez Palop M, Jovani V, Juan A, Judez E, Laffon A, Larrosa M, Lerma JJ, Linares LF, López Martín JA, Loza Cortina E, Loza E, Maiz O, Manero FJ, Marenco JL, Marras C, Marsal S, Martín Domenech R, Martínez A, Martín-Mola E, Mateo I, Matías MA, Maymo J, Mayordomo L, Mazzucchelli R, Medrano C, Medrano M, Mera A, Merino R, Mínguez M, Montero MD, Montes de Oca JV, Moreno J, Mulero J, Naranjo A, Navarro F, Navarro FJ, Noguera JR, Ortiz AM, Ortiz V, Panadero G, Pantoja L, Pascual E, Pascual C, Paulino FJ, Paulino M, Pecondón A, Peiró E, Pérez García C, Pérez Lidon G, Pérez Sandoval T, Pérez Torres F, Pina MF, Piqueras JA, Pujol M, Pujol J, Quevedo VE, Quiros J, Quirós J, Rejón E, Rivera J, Rodríguez Cros JR, Rodríguez Gómez M, Rodríguez Heredia JM, Rodríguez López M, Rodríguez Lozano C, Rodríguez-Valverde V, Román J, Ros I, Rosas JC, Roselló R, Rotes I, Rua Figueroa I, Ruiz MT, Saiz E, Sampedro J, Sánchez Andrada S, Sánchez-Andrade A, Sanmartí R, Santos G, Santos J, Tena X, Tenorio M, Tinture T, Tomero E, Tornero J, Torres C, Torresano M, Tovar JV, Toyos FJ, Trenor P, Tuneu R, Ureña I, Uriarte E, Urruticoechea A, Valdazo JP, Valero M, Valvanera M, Valverde J, Vázquez C, Vela P, Vesga JC, Vidal J, Villaverde V, Zarco P, Zea AC, Zubieta J. 